Volume 2 Nomor 1 November 2015 ISSN: 2407-7062 |e-ISSN: 2442-5435

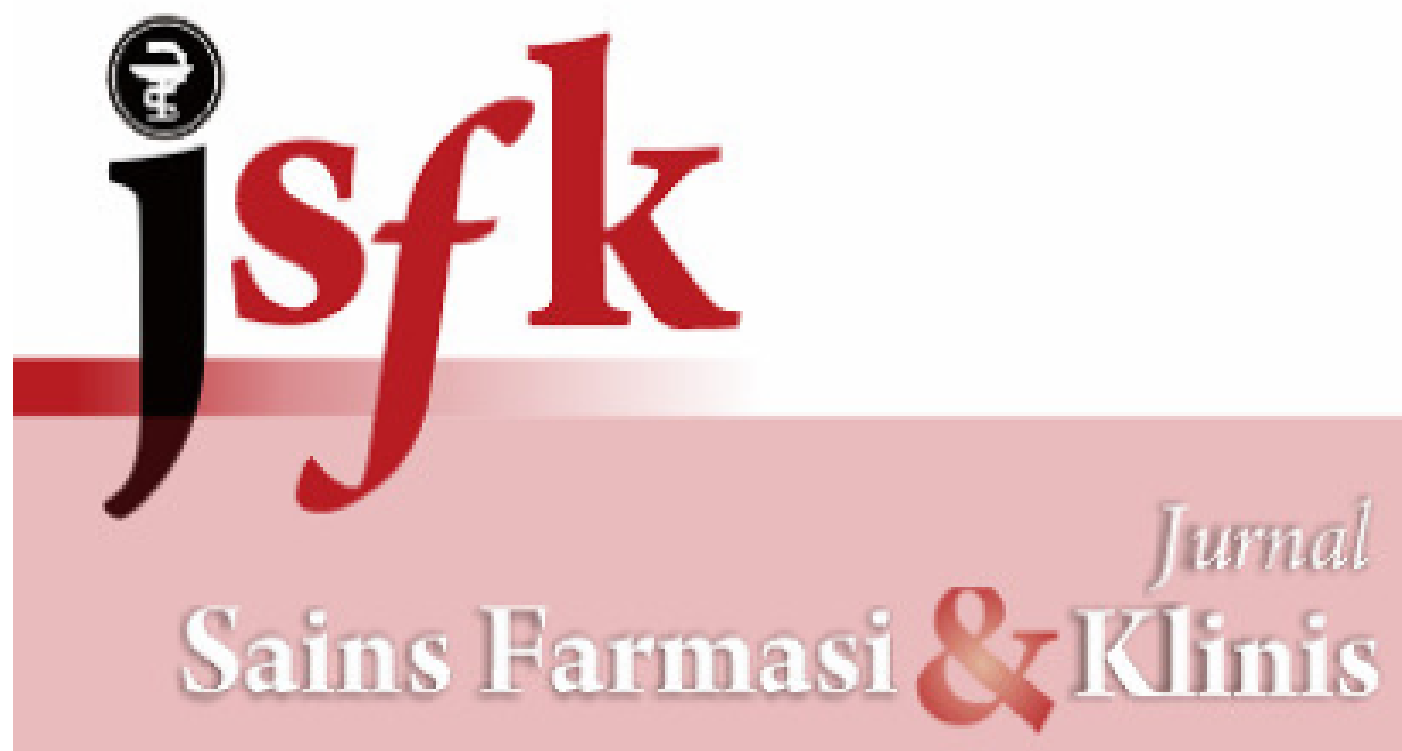

SEM don sipve hatosin MO dan dispors pedatno

Diterbitkan oleh:

the IKATAN AFOTIKER INDONISIA

GD IKATAN AFOTI

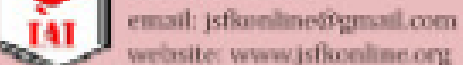

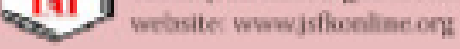




\section{Dewan Editorial}

\section{Editor in Chief}

Dr Erizal Zaini, Faculty of Pharmacy, Andalas University

\section{Managing Editor}

Yori Yuliandra, Fakultas Farmasi Universitas Andalas, Indonesia Ms Rahmi Yosmar, Fakultas Farmasi Universitas Andalas, Indonesia Ms Lili Fitriani, Fakultas Farmasi Universitas Andalas, Indonesia

\section{Editorial Board Members}

Dr Elfahmi Elfahmi, Sekolah Farmasi, Institut Teknologi Bandung, Indonesia

Dr Fatma Sri Wahyuni, Fakultas Farmasi Universitas Andalas, Indonesia

Prof Henny Lucida, Fakultas Farmasi Universitas Andalas, Indonesia

Dr Dwi Setyawan, Fakultas Farmasi Universitas Airlangga, Indonesia

Dr Khairunnisa Khairunnisa, Fakultas Farmasi Universitas Sumatera Utara, Indonesia

Dr Rika Yulia, Fakultas Farmasi Universitas Surabaya, Indonesia

Dr Dedy Almasdy, Fakultas Farmasi Universitas Andalas, Indonesia

Dr Yelly Oktavia Sari, Faculty of Pharmacy, Andalas University, Indonesia 


\section{Vol 1, № 2 (2015)}

\section{Daftar Isi}

Clinical Outcomes Penggunaan Antibiotik pada Pasien Infeksi Kaki Diabetik

3. Vusi Anggrioni, Mita Restinia, Venessya Cikita Mitokdo, Rochsismondoko Rochsismandoko, Tri Kusumoeni

dold 10.25077/jsfik.1.2.111-121.2015

Article view. 499 times

An Assay of Antioxidant Power of Methanolic Extract Various Type of Soybean

33. Riko Yulia, Azminoh Azminoh, Michello Michella, Andre Tonzil

dols 10.25077/jsfk. 1.2.122-131.2015

Article view. 190 times

Solubilsasi Parasetamol Dengan Ryoto® Sugar Ester dan Propilenglikol

3 . Deni Novizo, Nine Febrianti, Solmon Umar

doir 10.25077/jsfik. 1.2.132-139.2015

Article view. 1741 times

Pemeriksaan Residu Pestisida Profenofos pada Selada (Lactuca sativa L.) dengan Metode

33 Yohannes Alen, Zulhidayati Zulhidayoti, Netty Suhorti

[01] 10.25077/j5fk. 1.2.140-149.2015

Article view: 2025 times

Aktivitas Ekstrak Daun Suji (Dracaena angustifolia Roxb.) sebagai Antianafilaksis Kutan Aktif

3. Yufri Aldi, Muhammod Syofrudin, Elisma Elisma

doll 10.25077/jsfik. 1.2.150-158.2015

Article view. 717 times

Perbandingan Efektivitas Pendidikan Kesehatan terhadap Pengetahuan dan Kemampuan Ibu

33 Dwi Novriondo, Henny Lucido, Irfandy Soumariris

dol] 10.25077/jsfk. 1.2.159-169.2015

Article view. 1164 times

Pengembangan Instrumen Penilaian Kepuasan Pasien terhadap Pelayanan Kefarmasian di

93. Dedy Almasdy, Yulihasri Yulihosri, Dila Deria Putri

đold 10.25077//5fk.1.2.170-175.2015

Article view. 299 times 
Pengembangan Instrumen Penilaian Kepuasan Pasien terhadap Pelayanan Kefarmasian di

33. Dedy Almasdy, Yulihosri Yulihosri, Dila Deria Putri

[0i] 10.25077/j5fk. 1.2.170-175.2015

Article view. 299 times

Profil Disolusi Tablet Sustained Release Natrium Diklofenak dengan Menggunakan Matriks

33. Rini Agustin, Hestiory Rotih

[0i5 10.25077/j5fk.1.2.176-183.2015

Article view. 864 times

Isolasi dan Uji BSLT Ekstrak Etil Asetat Daun Meranti Sabut (Shore Ovalis (Korth.))

33. Enda Mora, Musyirna Rahma Nst, Emmo Susanti, Arfon Zasliadi

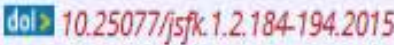

Article view. 422 times

Pengaruh Kombinasi Magnesium Stearat dan Talkum sebagai Lubrikan terhadap Profil

g3. Syofyan Syofyan, Tri Yanuarto, Moria Dona Octovio

하이 10.25077/jsfik. 1.2.195-206.2015

Article view. 1258 times

Pembuatan Dan Evaluasi Pati Talas (Colocasia esculenta Schoot) Termodifikasi dengan Bakteri

3. Wiro Noviana Suhery, Deni Anggroini, Novtofio Endri

dols 10.25077/j5fk.1.2.207-214.2015

Article view. 987 times 


\title{
An Assay of Antioxidant Power of Methanolic Extract Various Type of Soybean
}

Rika Yulia, Azminah, Michella \& Andre Tanzil

\begin{abstract}
Keywords: ABSTRACT: This study aimed to examine the antioxidant activity of methanolic Soybean (Glycine max L.Merill), Argomulyo variety, Burangrang variety, Ijen variety,

Kaba variety, antioxidant power, DPPH (1,1-Diphenyl-2extract of various type of soybean (Glycine max L.Merill) i.e Argomulyo, Burangrang, Ijen, and Kaba by using DPPH (1,1-Diphenyl-2-picryhydrazyl) method. The soybean was crushed, defatted using $n$-hexan, and extracted using methanol 90\%. The processes of defatting and extracting were conducted by kinesthetic maceration. Identification of flavonoid content using KLT and an assay of the antioxidant power of soybean were carried out qualitatively and quantitavely. Qualitative analysis, the color of DPPH solution was fading from violet into yellowish. Quantitative analysis showed that the maximum wavelength of DPPH in methanol was $516,00 \mathrm{~nm}$ within 15 -minute reaction time. The effective concentration 50\% (EC50) of each extract was alsa determined. picryhydrazyl) Results of this study revealed that the methanolic extract of soybean taken from varieties of Argomulyo, Burangrang, Ijen, and Kaba contained flavonoid, with EC50 value of each variety subsequently ranging from 3620.22 bpj; 5290.71 bpj; $4145.99 \mathrm{bpj}$; and $4253.50 \mathrm{bpj}$. Argomulyo variety showed the highest antioxidant power.
\end{abstract}

Faculty of Pharmacy, University of Surabaya

Korespondensi:

Rika Yulia

(rika.y73@gmail.com) 


\section{INTRODUCTION}

Nowadays, free radicals and antioxidant have become one of the issues the health practitioners frequently talk about. This is because most of the illnesses are claimed to be correlated with excessive oxidation reaction in the body. Such reaction initiates the forming of very active free radicals, which later results in cell or tissue impairment, autoimmune diseases, degenerative diseases and cancer (1).

Reactivity of free radicals might be hampered by means of antioxidant activities in a system. In fact, human's body already has natural antioxidant to reduce cell impairment. The problem is that free radicals could develop faster with the amount outweigh the natural antioxidant formed within the body. Therefore, there is a need for additional antioxidant intake to help protecting the body from free radicals and minimizing their negative effects. Flavonoid is wellknown as good antioxidant

Soybeans (Glycine max L.Merill) appear to be one of the plants contain flavonoids which is known as antioxidant component and which is widely spread and easily found in Indonesia. Soybeans contain flavonoid derivatives classified as fitoestrogen category and it is called isoflavones. The primary isoflavones contained in the soybeans are genistein and daidzein (1). Most of the isoflavones in the soybeans are available in the form of glycoside, only few in the aglycone form (2). The existence of sugar tied to aglycone isoflavone (glycoside form) causes glycoside isoflavone to dissolve more easily in the polar solution, such as ethanol, methanol, butanol, acetone, dimethylsulfoxide, dimethylformamide and water. Meanwhile, aglycones dissolve faster on ether and chloroform (3).

In Indonesia, Balai Penelitian Kacangkacangan dan Umbi-umbian, Malang (Balitkabi-Nuts and Tubers Research Center) has issued superior soybean varieties in Indonesia since 1918. By 2005, there had been 62 soybean varieties entitled to be superior (4). According to Lee et al. (2003), genetic and environmental influences contributed to the differences of genistein, daidzein and total isoflavone content. High content of total isoflavone is related to high antioxidant power (5).

Therefore, there should be studies on the determination of the antioxidant power of various type of soybean in Indonesia. This study examined the antioxidant power of four soybean varieties, i.e., Argomulyo, Burangrang, ljen, and Kaba by using DPPH (1,1-Diphenyl-2-picryhydrazyl) method. The antioxidant power of the soybeans (Glycine max L.Merill) in reducing free radicals DPPH was determined by calculation of the EC50 (Effective Concentration 50). EC50 is effective concentration to hamper or reduce $50 \%$ of free radicals. Accordingly, this study was expected to provide sufficient information regarding flavonoid contents and antioxidant power of methanolic extract of the four soybean varieties.

\section{METHODS}

\section{Research Materials}

The plants used in this study were soybean (Glycine max L.Merill) varieties of Argomulyo, Burangrang, ljen, and Kaba obtained from UPBS (Unit Pengelolaan Benih Sumber-Seed Source Management 
Unit) of Balitkabi (Nuts and Tubers Research Center), Malang on August 26, 2013. Those four varieties have been certified by Balitkabi, Malang.

\section{Chemical Substances}

The chemical substances utilized in this research included methanol p.a (Mallinckrodt Chemicals), n-hexan p.a (Mallinckrodt Chemicals), DPPH (1,1-Diphenyl-2picryhydrazyl), Silica gel GF254 (Merck), aquadem (Chemistry Laboratory of University of Surabaya).

\section{Equipment}

This research utilized an analytical scale (AND GR-202), kinetic macerator (Stirring Motor IKARw 20 N) with 10 rpm stirring speed, rotary evaporator (heidolph), Ultrasonic cleaner (Branson 1200), electric waterbath, filter paper Whatmann, blender, siever mesh 20, stopwatch, spectrophotometer UVVisible (Shimadzu U-1800), Chromatography instrument (CAMAG), capillary pipes $5 \mu \mathrm{l}$, and laboratory glasses.

\section{Preparation of the Research Materials}

Each of soybean variety was cleaned, dried in natural air, and later mashed using the blender. The powder obtained was sifted using siever mesh 20. Finally, the powder of each variety was scaled up to $300 \mathrm{~g}$ each.

\section{Extraction of the Soybeans}

Firstly, the soybean powder was macerated kinetically using $1 \mathrm{~L} n$-hexan for an hour. Then, it was left unprocessed for 24 hours. After 24 hours, it was sifted into a container, while the residue was re-extracted using $\mathrm{n}$-hexan. The maceration process using n-hexan was conducted 5 times.
The results of all the five processes were collected in a container. This procedure was done to extract the oil from soybean seeds.

Secondly, the residue was macerated kinetically using $1 \mathrm{~L}$ methanol $90 \%$ for an hour. It was let unprocessed again 24 hours. The results, then, sifted into a container and the remains were macerated using the same technique. The kinetic maceration using methanol $90 \%$ was conducted for 4 times. The results of the first, second, third, and fourth processes were collected in one container. The liquid extract was later concentrated by means of rotary evaporator to one third of the initial volume. The concentration process was continued in electric water bath until viscous extract with constant weight was obtained.

\section{Identification of Flavonoid in Methanol Extract of Soybeans}

The viscous extract of the soybeans was later dissolved in water, then it was extracted by using chloroform for 3 times 10 $\mathrm{ml}$ in separate funnels. A qualitative analysis of chloroform fraction was conducted using a thin layer chromatography (TLC) method to identify the presence of flavonoid in the extract. The stationary phase used included silica gel GF254 (Merck) and the mobile phase was a mixture of CHCL3:ethyl acetate (60:40). As much as 3 to 4 capillaries of the extract were gently tapped ontoTLC plate and eluted after saturation of the chromatographic chamber. The plate was then examined under the UV rays of $365 \mathrm{~nm}$, flavonoids showed yellow, blue and green fluorescence.

Qualitative Measurement of the Antioxidant Power of methanolic Extract of Soybeans (Glycine max L.Merill) using 


\section{DPPH Method}

Each variety of the soybeans was scaled as much as $300 \mathrm{mg}$ and $50,0 \mathrm{~mL}$ methanol was added (stock solution 6000 bpj). The stock solution was diluted with methanol to obtain concentrations $1200,2400,3600$ and $4800 \mathrm{bpj}$ respectively. Then, $1.5 \mathrm{ml}$ of each solution (1200 bpj, 2400 bpj, 3600 bpj, $4800 \mathrm{bpj}$, and $6000 \mathrm{bpj}$ ) was drawn into a pipette and 3,0 mL, 40,0 bpj DPPH solution was added. Each of solution sample was evaluated in terms of the color change (the purple color of DPPH solution would turn into pale yellow and finally colorless).

\section{Determination of the Maximum Wave- Length}

As much as $3.0 \mathrm{ml}$ of DPPH solution $40.0 \mathrm{bpj}$ and $1.5 \mathrm{ml}$ of methanol were put in a test tube, shaken homogeneously, and finally observed in terms of the absorbance in $\lambda$ 400-700 $\mathrm{nm}$. The wave-length with the highest absorbance was the maximum wave-length.

\section{Determination Reaction Time}

As much as $3.0 \mathrm{ml}$ of DPPH solution $40.0 \mathrm{bpj}$ and $1.5 \mathrm{ml}$ of methanol were put ini a test tube, shaken homogeneously, and finally observed in terms of the absorbance in $\lambda 400-700 \mathrm{~nm}$ within the interval of 5,10 , $15,20,25$, and 30 minutes. As a comparison, $3.0 \mathrm{ml}$ of DPPH solution $40.0 \mathrm{bpj}$ and $1.5 \mathrm{ml}$ of methanol were used.

\section{Quantitative Measurement of the Antioxidant power of the Soybean Methanolic Extract}

3,0 mL 40,0 bpj DPPH solution and 1,5 $\mathrm{mL}$ sample solution at various concentration $(1200,2400,3600,4800$, and $6000 \mathrm{bpj})$ were mixed homogenously and left for a period of time to provide optimum reaction (based on the reaction time determined previously). Afterwards, the mixture was observed at the maximum wave-length. As a comparison, 3.0 $\mathrm{ml}$ of DPPH $40.0 \mathrm{bpj}$ and $1.5 \mathrm{ml}$ of methanol were used. This activity was replicated for 3 times.

\section{Data Analysis}

The antioxidant power was calculated from the percentage of damping by using the following formula:

$\%$ of damping $=\left[1-\left(\frac{\text { The absorbance of sample solution }}{\text { The absorbance of control solution }}\right)\right] \times 100 \%$

If the value showed $0 \%$, the solution had no free radical damping power, on the other hand, if the value showed $100 \%$ value, it implied that the solution totally had damping power. The testing needed to be continued by diluting the sample solution in order to observe its concentration limit.

The percentage (\%) of the damping at various concentration was later put into regression equation with extract concentration (bpj) as the axis (X) and the percentage value of the damping as the ordinate $(Y)$. The value of EC50 was obtained from calculating the percentage of damping as much as $50 \%$. In this study, The value of EC50of 4 soybean varieties will be compared using statistics method of One-way ANOVA. EC50was an effective concentration to hamper or to reduce $50 \%$ of free radicals (6).

From the linear regression equation of concentration vs damping percentage, correlation between the sample solution concentration $(X)$ and the percentage of damping $(Y)$ could be attained by calculating the correlation coefficient $r(\alpha=0.05)$. If the 
value of $r$ is bigger than the value of $r$ listed in the table within $\alpha=0.05$, it entailed that there was a significant correlation between the concentration of sample solution and the percentage of the damping (7).

\section{RESULTS AND DISCUSSION}

Extraction of Soybeans (Glycine max L.Merill) Using Methanol $\mathbf{9 0 \%}$

From $300 \mathrm{gr}$ of soybean powder of each
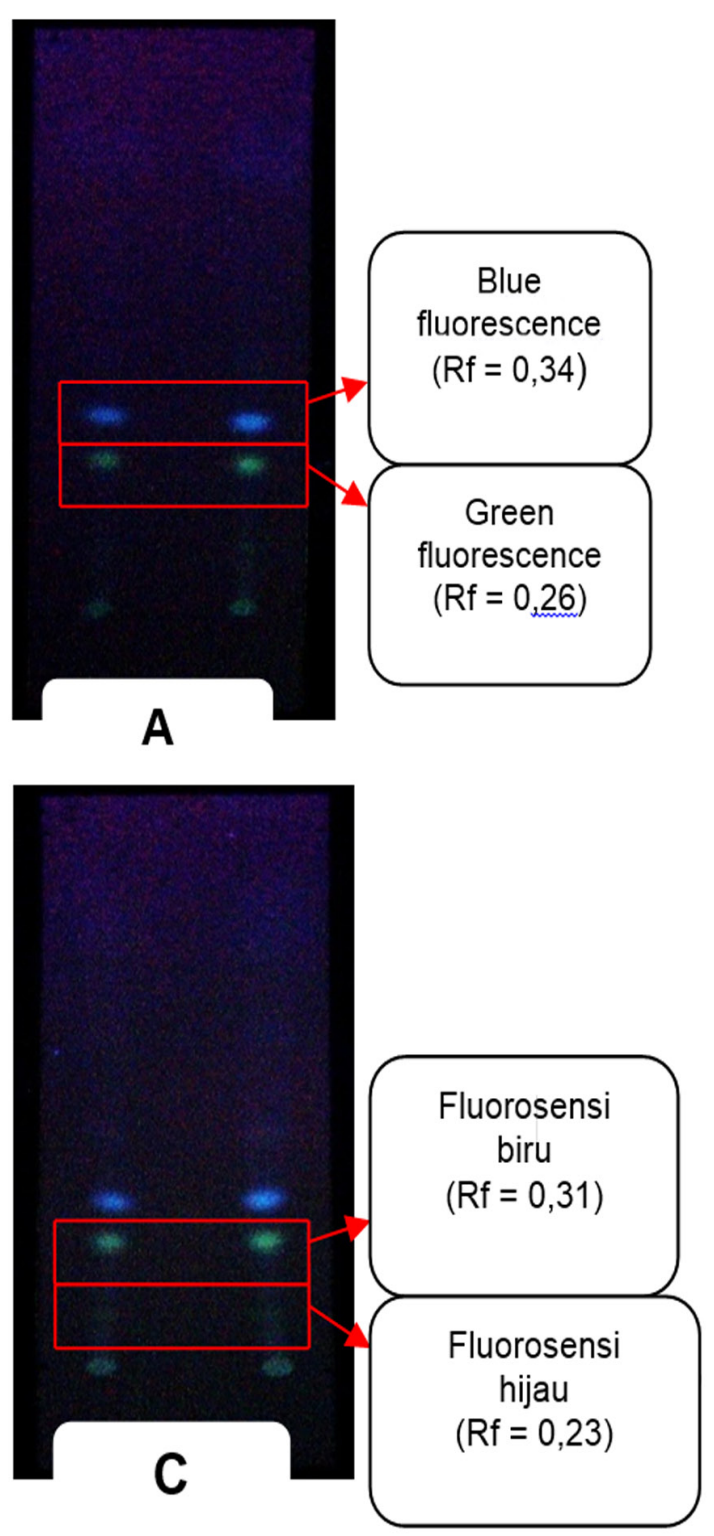

Figure 1. TLC Chromatogram of Chloroform Fraction of methanolic Extract of Soybean Observed under UV Ray $\lambda 365 \mathrm{~nm}$ a. Argomulyo

b. Burangrang c. ljen d. Kaba variety, viscous extract of each soybean variety was obtained. As much as 27.96 grams of Argomulyo variety, 28.94 gram of Burangrang variety, 29.35 gram of Ijen variety, and 28.11 gram of Kaba variety were obtained.

\section{Identification of Flavonoid in the Methanol Extract of Soybeans (Glycine max L.Merill)}

Qualitative analysis of flavonoid in each extract was done by using TLC method
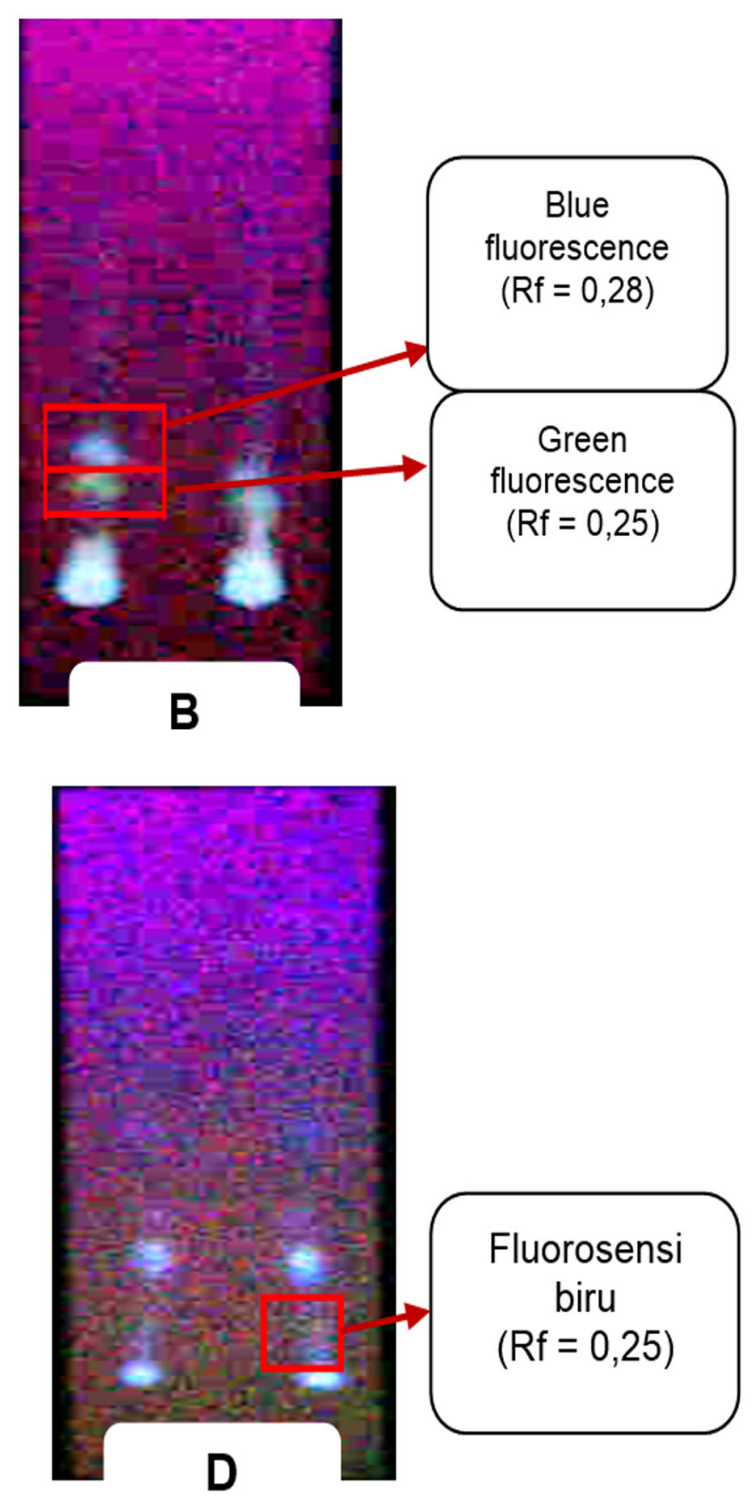
(Figure 1) Figure 1 showed blue and green fluorescence stain on the plate that was spotted with chloroform phase from each methanol extract of soybean variety observed under UV ray at $\lambda 365 \mathrm{~nm}$. The presence of blue and green fluorescence stain entailed that there was flavonoid in the methanolic extract of those four varieties (Argomulyo, Burangrang, ljen and Kaba).

The results of the observation of the antioxidant power of methanol extract of soybeans Soybean (Glycine max L.Merill) of Argomulyo, Burangrang, ljen, and Kaba varieties using $\mathrm{DPPH}$ methodat various concentration using DPPH solution 40.0 bpj could be seen in Figure 2, Figure 3, Figure 4, Figure 5 . In the figures, the test tube containing $3.0 \mathrm{ml}$ DPPH $40.0 \mathrm{bpj}+1.5$ $\mathrm{ml}$ of methanol extract solution of soybean (sample) at various concentrarion. From the

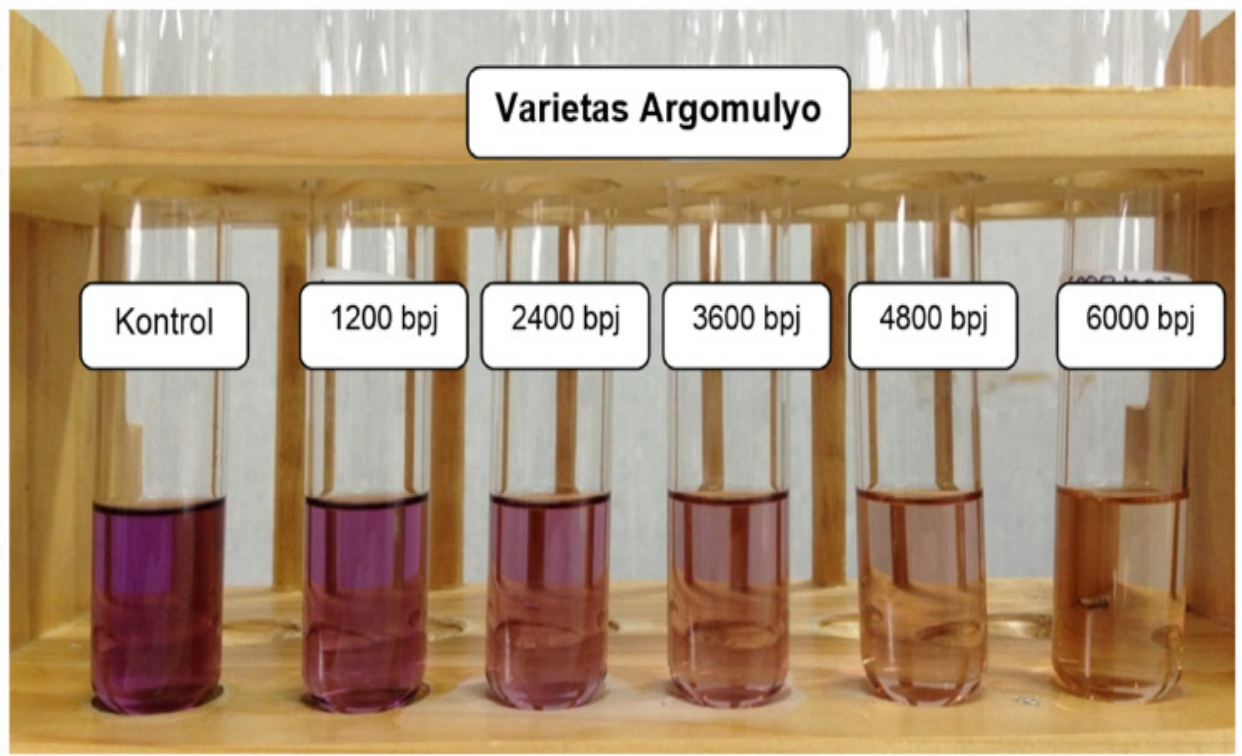

Figure 2. The Results of Qualitative Testing of Antioxidant Power Using DPPH Method of Methanol Extract of Soybean of Argomulyo variety

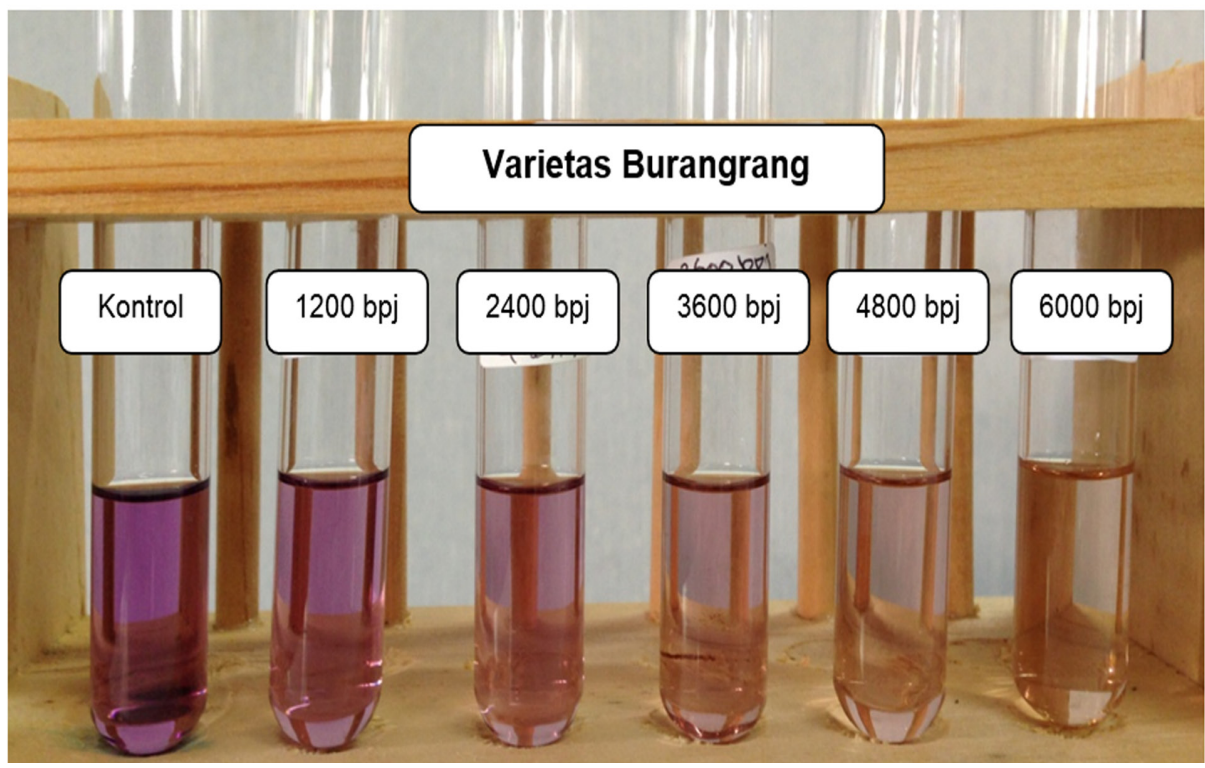

Figure 3. The Results of Qualitative Testing of Antioxidant Power Using DPPH Method of Methanol Extract of Soybean of Burangrang variety 
left to the right, in the sample concentrations, i.e., 1200 bpj, 2400 bpj, 3600 bpj, 4800 bpj, and $6000 \mathrm{bpj}$, there could be seen that the higher the concentration, the more the color of DPPH solution faded. It implied that there were more DPPH free radicals being reduced by the antioxidant available in the sample. The fading violet color of DPPH free radicals was caused by the reduction of DPPH when its molecules that had one
$\mathrm{N}$ atom whose electrons were not in pairs reacted with a compound that could donate hydrogen atoms (8).

\section{Determination of the DPPH maximum wavelength}

The maximum wave-length of DPPH solution 40.0 bpj measured at wavelength 400-700 nm was $516.00 \mathrm{~nm}$. This wavelength was used to determine rection time

Figure 4. The Results of Qualitative Testing of Antioxidant Power Using DPPH Method of Methanol Extract of Soybean of Ijen variety

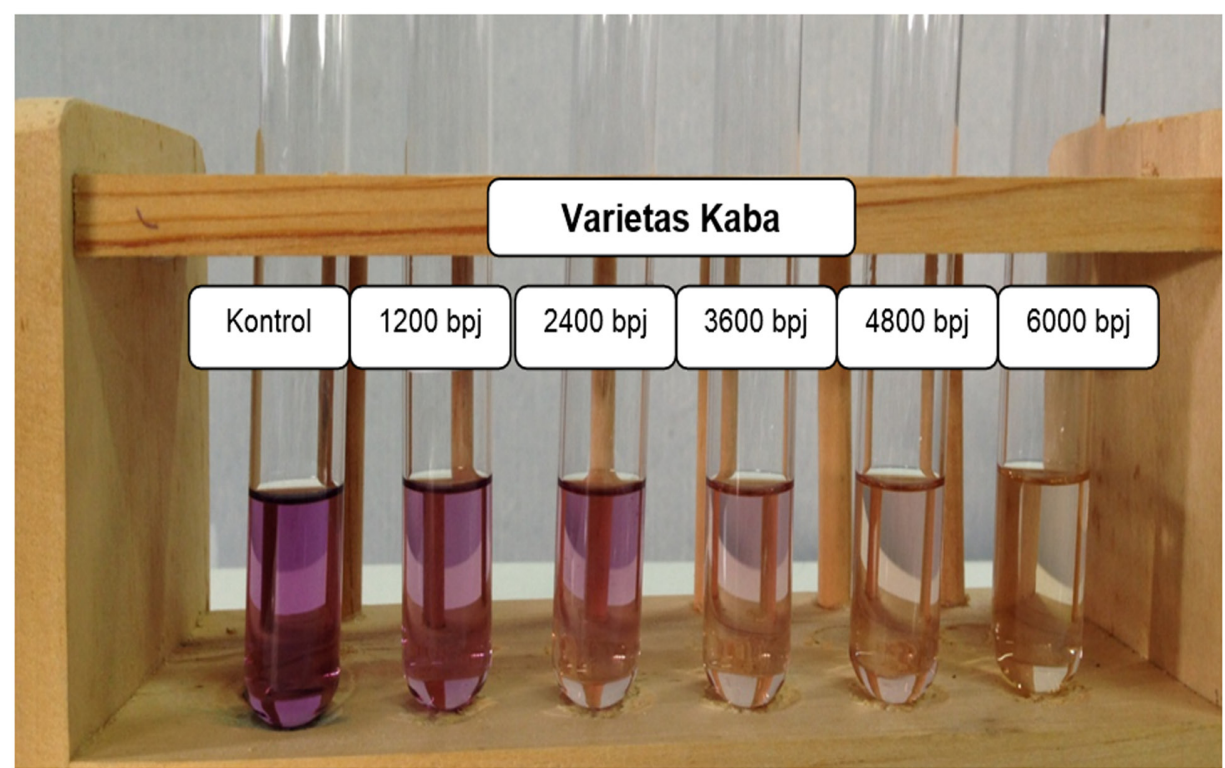

Figure 5. The Results of Qualitative Testing of Antioxidant Power Using DPPH Method of Methanol Extract of Soybean of Kaba variety 
and to examine the antioxidant power of the sample. The measurement of the maximum wave-length of DPPH in the methanol was carried out because every absorbance measurement of the tested solution was conducted at that wave-length as any change in absorbance of each concentrate unit was deemed to be the biggest. The data indicated a maximum sensitivity of the analysis

\section{Determination of the reaction time}

By defining the reaction time methanolic of the four varieties of methanolic extract of soybean, it was found out that at minute 15th, the reaction of DPPH free radicals and the antioxidant in the methanolic extract of the soybeans of each variety was optimal. It could be seen from the difference of absorbance reduction at minutes 15th and 20th was relatively smaller and the time used was more efficient.

\section{The Linear Regression Equation and EC50 of Methanol Extract of Soybeans (Glycine max L.Merill)}

Based on the calculation of $\%$ of damping, a linear regression equation of concentration (bpj) and \% of damping was formulated. The equation and value of EC50 of each replication of the methanol extract of the tested soybeans were presented in tables 1-4 The value of calculated $r$ from each linear regression equation was compared to table $r$. It was clear that calculated $r$ was greater than the table $r$ (0.878). this data confirmed the correlation between that there was a significant correlation between concentration and \% of damping. The EC50 parameter was in inverse proportion to the antioxidant activity; the lower the value of EC50, the greater the antioxidant activity of a compund (8).

From the calculation of linear regression equation, the mean value of EC50 of methanol extract of soybean of Argomulyo variety was $3630.22 \mathrm{bpj}$, of Burangrang variety was as much as $5290.71 \mathrm{bpj}$, of ljen variety was $4145.99 \mathrm{bpj}$, and of Kaba variety was 4253.50 bpj respectively. Argomulyo variety showed the greatest antioxidant power with the lowest of value of EC50 compared with another varieties using One-Way ANOVA method.

Tabel 1. Linear Regression Equation and EC50 Value of Methanol Extract of Soybean (Glycine max L.Merill) of Argomulyo variety

\begin{tabular}{|c|c|c|c|c|}
\hline Replication & $\begin{array}{l}\text { Linear } \\
\text { Regression } \\
\text { Equation }\end{array}$ & Calculated $r$ & $\begin{array}{l}\text { The table } r \\
(\alpha=0,05 \\
n=5)\end{array}$ & $\begin{array}{l}\text { EC50 } \\
\text { (bpj) }\end{array}$ \\
\hline I & $\begin{aligned} y= & 1.0933 \times 10-3 x \\
& +12.0780\end{aligned}$ & 0.994 & 0.878 & 3468.58 \\
\hline II & $\begin{aligned} y= & 1.0725 \times 10-3 x \\
& +10.4600\end{aligned}$ & 0.995 & 0.878 & 3686.71 \\
\hline \multirow[t]{2}{*}{ III } & $\begin{aligned} y= & 1.0672 \times 10-3 x \\
& +10.1360\end{aligned}$ & 0.991 & 0.878 & 3735.38 \\
\hline & & & $\begin{array}{l}\text { Mean } \\
\% \mathrm{Kv}\end{array}$ & $\begin{array}{l}3630.22 \\
3.91 \%\end{array}$ \\
\hline
\end{tabular}


Tabel 2. Linear Regression Equation and EC50 Value of Methanol Extract of Soybean (Glycine max L.Merill) of Burangrang variety

\begin{tabular}{|c|c|c|c|c|}
\hline Replication & $\begin{array}{l}\text { Linear } \\
\text { Regression } \\
\text { Equation }\end{array}$ & Calculated $r$ & $\begin{array}{l}\text { The table } r \\
(\alpha=0,05 ; \\
n=5)\end{array}$ & $\begin{array}{l}\text { EC50 } \\
\text { (bpj) }\end{array}$ \\
\hline I & $\begin{aligned} y= & 8.5268 \times 10-3 x \\
& +7.1300\end{aligned}$ & 0.995 & 0.878 & 5027.68 \\
\hline II & $\begin{aligned} y= & 7.8169 \times 10-3 x \\
& +7.4590\end{aligned}$ & 0.996 & 0.878 & 5442.17 \\
\hline \multirow[t]{2}{*}{ III } & $\begin{aligned} y= & 8.0523 \times 10-3 x \\
& +6.4990\end{aligned}$ & 0.998 & 0.878 & 5402.28 \\
\hline & & & $\begin{array}{l}\text { Mean } \\
\% \mathrm{Kv}\end{array}$ & $\begin{array}{l}5290.71 \\
4.32 \%\end{array}$ \\
\hline
\end{tabular}

Tabel 3. Linear Regression Equation and EC50 Value of Methanol Extract of Soybean (Glycine max L.Merill) of ljen variety

\begin{tabular}{|c|c|c|c|c|}
\hline Replication & $\begin{array}{l}\text { Linear } \\
\text { Regression } \\
\text { Equation }\end{array}$ & Calculated r & $\begin{array}{l}\text { The table } r \\
(\alpha=0,05 \\
n=5)\end{array}$ & $\begin{array}{l}\text { EC50 } \\
\text { (bpj) }\end{array}$ \\
\hline I & $\begin{aligned} y= & 9.2027 \times 10-3 x \\
& +10,6460\end{aligned}$ & 0.991 & 0.878 & 4276.35 \\
\hline II & $\begin{aligned} y= & 1.0139 \times 10-3 x \\
& +9,3420\end{aligned}$ & 0.997 & 0.878 & 4010.06 \\
\hline III & $\begin{aligned} y= & 9.4762 \times 10-3 x \\
& +10,6590\end{aligned}$ & 0.994 & 0.878 & 4151.56 \\
\hline
\end{tabular}

$\% \mathrm{Kv} 3.21 \%$

Mean 4145.99

Tabel 4. Linear Regression Equation and EC50 Value of Methanol Extract of Soybean (Glycine max L.Merill) of ljen variety

\begin{tabular}{|c|c|c|c|c|}
\hline Replication & $\begin{array}{l}\text { Linear } \\
\text { Regression } \\
\text { Equation }\end{array}$ & Calculated $r$ & $\begin{array}{l}\text { The table } r \\
(\alpha=0,05 \\
n=5)\end{array}$ & $\begin{array}{l}\text { EC50 } \\
\text { (bpj) }\end{array}$ \\
\hline 1 & $\begin{aligned} y= & 9.1642 \times 10-3 x \\
& +9,6160\end{aligned}$ & 0.997 & 0.878 & 4406.72 \\
\hline II & $\begin{aligned} y= & 9.2176 \times 10-3 x \\
& +10,0870\end{aligned}$ & 0.996 & 0.878 & 4330.11 \\
\hline \multirow[t]{2}{*}{ III } & $\begin{aligned} y= & 10.3363 \times 10-3 x \\
& +8,4100\end{aligned}$ & 0.996 & 0.878 & 4023.68 \\
\hline & & & $\begin{array}{l}\text { Mean } \\
\% \mathrm{Kv}\end{array}$ & $\begin{array}{l}4253.50 \\
4.77 \%\end{array}$ \\
\hline
\end{tabular}




\section{CONCLUSION}

The methanolic extract of soybean seeds (Glycine max L.Merill) of Argomulyo, Burangrang, Ijen, and Kaba varieties contained flavonoid. Also, all those four resulted in EC50 values subsequently as

\section{REFERENCES}

1. Winarsi H, 2007, Antioksidan Alami dan Radikal Bebas: Potensi dan Aplikasinya dalam Kesehatan, Kanisius, Yogyakarta, 11-22, 77-82.

2. Lee Jae-Hwan, Marjory R, Ronald JF, Steve K, Martin ST, Steven JS, Yael V, 2004, Isoflavone Characterization and Antioxidant Activity of Ohio Soybeans, Journal of Agricultural and Food Chemistry, 52:2647-2651.

3. Markham KR, 1982, Cara Mengidentifikasi Flavonoid, Bandung, Penerbit ITB, pp. 13-15.

4. Suhartina, 2005, Deskripsi Varietas Unggul Kacang-kacangan dan Umbiumbian, Malang, Balai Penelitian Tanaman Kacang-kacangan dan Umbiumbian.

5. Mujic, Sertovic E, Jokic S, et al, 2011, Isoflavone Content and Antioxidant Properties of Soybean Seeds. Croat. J. much as 3620.22 bpj; 5290.71 bpj; 4145.99 bpj; and $4253.50 \mathrm{bpj}$. Argomulyo variety had the greatest antioxidant power among the tested varieties.

Food Sci. Technol. 3 (1): 16-20.

6. Marxen K, Vanselow KH, Lippemeier $S$, et al, 2007, Determination of DPPH Radical Oxidation Caused by Methanolic Extracts of Some Microalgal Species by Linear Regression Analysis of Spectrophotometric Measurements. Sensors. 7: 2080-2095.

7. Hadi S, 2000, Analisis Regresi jilid 1 Cetakan ke-7, Penerbit Andi, Yogyakarta, 68.

8. Molyneux P, 2004, The Use of Stable Free Radical Diphenylpicrylhydrazyl (DPPH) for Estimating Antioxidant Activity, Songklanakarin Journal of Science and Technology 26(2):211219.

9. Suharman, MM, 1995, Analisis Instrumental, Surabaya, Airlangga University Press, pp. 52-57 